\title{
動向情報編纂のためのテキストからの統計量表現 の自動抽出
}

\section{Automated Extraction of Statistical Expressions from Text for Infor- mation Compilation}

\author{
森 辰則 \\ Graduate School of Environment and Information Sciences, Yokohama National Univeristy \\ mori@forest.eis.ynu.ac.jp, http://www.forest.eis.ynu.ac.jp/ mori/ \\ 藤岡 篤史
Atsushi FUJIOKA \\ 横浜国立大学 大学院 環境情報学府 \\ Graduate School of Environment and Information Sciences, Yokohama National Univeristy \\ fujioka@forest.eis.ynu.ac.jp \\ 村田 一郎同上) \\ Ichiro MURATA ichiro@forest.eis.ynu.ac.jp
}

keywords: MuST(Multimodal Summarization for Trend Information), statistical expressions, information extraction

\section{Summary}

In order to summarize trend information in document and visualize it, we have to have a method to automatically extract statistical information from document. In this paper, we investigate automated extraction of statistical information, especially, expressions of name of statistical information. First, we classify those expressions into three categories, namely, the action type, the attribute type, and the definition type. Second, the internal structures of them are examined. According to the internal structures, we defined an XML tag set to annotate each part of names of statistical information. As a feasibility study of automated extraction of them, we conducted an experiment in which parts of names of statistics are extracted by using a standard chunking algorithm. The experimental result shows that the parts of names of statistics defined by the tag set can be extracted with good accuracy in the case that we can prepare a training corpus of the domain similar to target documents. On the other hand, the extraction accuracy will be degraded when we cannot prepare such a training corpus.

\section{1.は じめに}

ある製品の価格や売上状況，内閣支持率などの動向情 報に対する関心に, 要約や可視化, また产れらを組み合 わせたマルチメディアプレゼンテーションで答える研究 が行われている[加藤 04] ·文書に現れる動向情報を集約 して产の要約と可視化を行う場合には, 文書から統計量 に関する情報を抽出する必要がある。例えば，例文 (1)

(1)「大手自動車メーカーが2 4日に発表した10月の国 内生産実績によると，トヨタ自動車は14万台と前年実 績を上回った 」

においては，表現「10月の国内生産実績」，「トヨタ自 動車」から推定される「トヨタ自動車の10月の自動車 の国内生産実績」という統計の調査方法と，光れに対応 する值を表現する「14万台」の組が統計量の抽出結果 となる、本稿では, 前者の文書中における表出を統計量 名と定義し，兴の自動抽出を検討する、特に，動向情報
の集約を念頭に置き，統計量名を成す構成要素を分類さ れた部品として抽出することを目標とする．光のために， まず, 統計量名を分類し, 光の内部構造を検討する. 光し て, 光の内部構造に応じ, 統計量名の構成要素に対し注 釈づけを行なうための XML タグセットを定義する.さ らに, 自動抽出の実現可能性を調べるために, 標準的な 情報抽出手法により，これら構成要素がどれくらいの精 度で抽出できるかを調べる。

なお，統計量を構成するもののうち，值に対応する表 現の抽出は, 比較的容易にできると考えて, 本稿では考 察の対象から除く.

\section{2. 先 行 研 究}

統計情報の抽出に関して, 斉藤ら [斉藤 98] は数值の 周囲の言語表現を調心，語彙統語パタンを構築，弚れを 抽出対象文書に当てはめることで統計量の抽出を試みて 
いる. また，藤畑ら [藤畑 01] は数值表現に対する係り受 けの制約を考察し，弚れに基づく優先規則を用いた情報 抽出を提案している.いずれの研究でも統計量名は数值 と関連のある名詞であるとされているが，どこまでを統 計量名として抽出すれば十分であるかということは十分 に考察されていない .

一方, 動向情報を扱った研究の多くは, 動向情報の要 約と可視化に関するワークショップ (MuST)[加藤 04] に おいて報告されている. 村田ら [村田 06] は記事に出現 する表現の頻度などの情報を基に , 一記事から一つの動 向情報の抽出を行っている. 斎藤ら [斎藤 07] は, 同一記 事に現れる複数の統計量表現を, 接尾表現に注目して抽 出する手法を検討している．

これら先行研究に対し, 本稿では統計量名を構成する 表現が何であるかを検討し，谷の構成要素を種別毎に区 別して抽出をすることを目標としている点が異なる．

\section{3. 統計量名の捉え方とその自動抽出}

\section{$3 \cdot 1$ 文章中の表現と統計量との間の関係} 次の二つの例文を考えよう .

(2)「Aビールが発表した 3 月のビール出荷量は，200 万ケースだった 」

(3) $\ulcorner 4$ 月の A のビール出荷数量は，2 20 万ケース . 統計量については,どのような統計であるかを表す表現 (例えば， 4 月のAのビール出荷数量」) と対応する值を 表す表現(例えば， 220 万ケース」)の組て現れている． 本稿では特に複雑な構造を持つ前者に注目をする．さて， 二つ例のいずれにおいても , $($ 月別の $) A$ ビール社のビー ルの出荷量」に言及している点で共通しているが, 弚れ

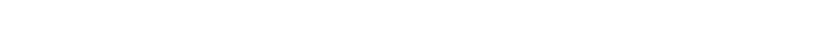
なっている.複雑な統計量を収集して動向情報として集 約するためには，このような共通部分と差異部分を区別 できる必要がある.更に, 同じ統計量でも，どこが共通 部分となり差異部分になるかは, どのような軸で統計量 を収集するかによって変わるために, 兴の部分構造を適 切な種類に区別して認識することが要求される.

一方で, 統計量に関する情報が文章中に現れる際の表 記の多樣性についても考慮する必要がある.上記の例で は $「 \mathrm{~A}$ ビール」と「A」「出荷量」と「出荷数量」の关れ

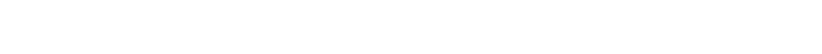

上記の各点に対応するために, 我々は, 二つの概念, 統 計の調査方法ならびに統計量名を以下のように定義・導 入し，統計量の整理を試みる。

統計の調查方法 ある統計量の值がどのように統計を取っ て得られたのかを示す概念 . 文章中に現れるもので はない . ( 「3月のAビール社のビール出荷量」に対 応する概念) .

統計量名 統計の調査方法を指し示すために文章中に表 出する表現を分類し組み合わせたもの. 例えば , 後

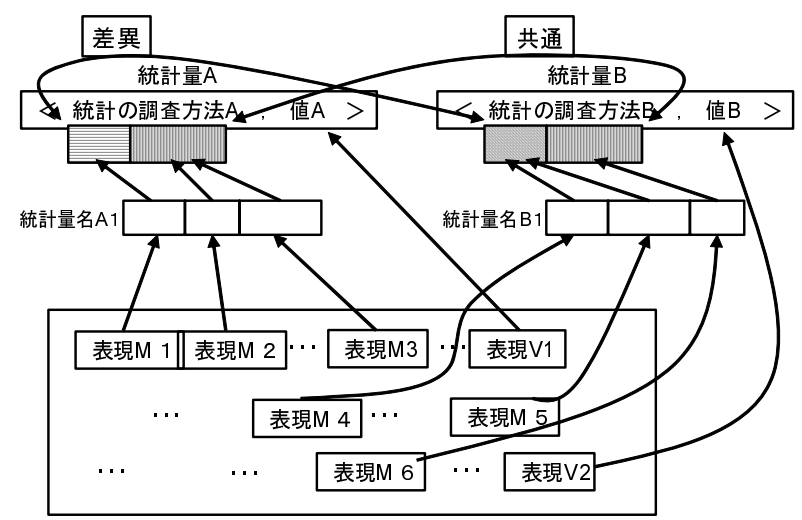

図 1 文章中に現れる統計量表現の構造

述の分類に従うと例文 (2) の統計量名は \{agent: A ビール, time: 3 月, obj:ビール, foot:出荷, head:量 \}となる .

統計量 ある「統計の調査方法」と，光れに対応する值 の組 .

統計の調査方法を指し示す統計量名と，值を指し示す表 現の組が文章中に現れている場合に，動向情報として利 用することができる．表現の多樣性は，同一の「統計の 調査方法」を指し示す「統計量名」の多樣性に帰着して 考える .上記の関係の概略を图 1 に示す. 統計量名の構 成要素は文章中に分散していることもあり得る点に注意 されたい.

\section{$3 \cdot 2$ 統計量名の抽出タスクの構造}

統計量名を構成する部品は文章中に形態素の連続とし て出現するとは限らず，離れて表出する場合が多い，例 えば，

（4）「国内のビール大手 5 社は 13 日，1月の課税出荷数 量を発表した . 全体の数量は 305 万 4000 ケースで, 前年同月比 $125 \%$ と好調な滑り出し 。

という文章では，「1月」,「課税出荷数量」,「全体の数 量」が組み合わさって統計量名を構成している．本稿で は，これら統計量名の部品となる個別の表現を統計量名 の要素と呼ぶことにする . 文書から統計量名を抽出する ためには, 統計量名がこのような複数の要素から構成さ れていると考え，各表現を役割に応じて分類して抽出す る手法が必要である。

統計量名の要素を個別に抽出した後は，更に，適切な 要素を組み合わせ ,一つの統計量名を構成しなければな らない, 例えば，

(5)「18日に発表した5月の国内生産の実績によると， 日産自動車は前年比 $22 \cdot 8 \%$ 減, 卜ヨ夕自動車は同 2 $0 \cdot 4 \%$ 減となった .

という文において，「5月」,「国内生産」,「日産自動車」, 「トヨタ自動車」か流計量名の要素であり，光れらが結び 付いて $\ulcorner 5$ 月の日産自動車の国内生産」,「5 月のトヨタ 
自動車の国内生産」という 2 つの統計量名ができると判 断する過程を, 要素の抽出過程とは別に考察する必要が ある．乥こで本稿では，統計量名の抽出を以下の 2 つの タスクに分けて考える。

・文章中から統計量名の要素となるものすべてを取り 出すタスク．

・取り出された要素を組み合わせて 1 つの統計量名を 作るタスク .

また ここまでで取り出された統計量名は単なる要素の 組み合わせであるが , これを元に要約や統計情報の可視 化を行おうと考えた場合，対応する「統計の調査方法」 が何であるのかを復元し, 同種の統計量を集める必要が ある. 光の基本は，

・統計の調査方法が同じものを判定するタスク .

である．なお，統計の調査方法自身は直接表現には現れ ないものであるから，弚れぞれの統計量名の中で共通部 分と差異の部分を認識するタスクで代替することになる と考えられる .

本稿の以降の部分では, 上記 1 つ目のタスクに注目す る.特に, 統計量名の各要素の分類を考察し, 兴れらの 自動抽出を試みる. 残りの 2 つのタスクについては，今 後の課題としたい .

\section{4. 統計量名の種類とその内部構造}

\section{$4 \cdot 1$ 統計量名の種類}

統計量名の要素としてどのような表現が出現するかを， MuST コーパスならびにいくつかの新聞記事において調 查した . 光の過程において, 統計量名の要素の現れ方の 違いによって，統計量名には少なくとも，次例に示す 3 種類が存在することが分かった .

(6)「1998年度のパソコンの国内出荷台数は 735 万 台と前年度比 $10 \%$ 増で, 前年害績を上回った。

(7) $\ulcorner 17$ 日に中東のドバイ原油価格は1 バレル当たり 9 . 98 ドルであった 」

(8)「1月の景気動向指数は $62 \cdot 5 \%$ となり, 景気判断 となる分かれ目である $50 \%$ を越えた 。

例文 (6) は，ある動作によって生じた物の統計量を扱う ものである.一方で，例文 (7) はある物の状態や性質が 統計量となっているものである . 前者には, 動作に関与 する動作主や動作自身が統計量名の一部として現れるが， 後者は物の状態であるので, 属性名が現れる . 例えば, 例文 (6) は，あるメーカが動作主となって「出荷」とい う動作を行なった対象「パソコン」について，「台数」と いう数え方て計数した統計量の記述となっている.一方， 例文 (7) では対象「原油」の光のものの属性を表す属性 「価格」が統計量である．また，例文 (8) では表現「景気 動向指数」が統計量名の主要部を成すが，これは外部で 定義された計算方式に対する固有の名前であり，内部構 造を持たない，本稿では，以上の例文に示される統計量

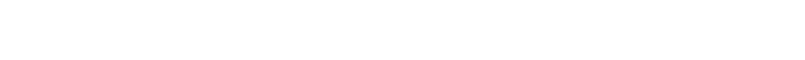
ことにする

\section{$4 \cdot 2$ 統計量名の内部構造}

ここでは $4 \cdot 1$ 節で分類した 3 種類の統計量名について，

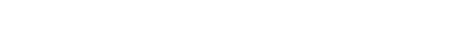

\section{$\S 1$ 動作型の統計量名の内部構造}

例文 (6)の「1998 年度のパソコンの国内出荷台数」 という統計量名は,「1998年度」「「パソコン」「国内出 荷台数」という要素から構成されている「パソコン」と いう要素は統計を取る「対象」である「出荷台数」は言 い換えると「出荷された台数」であるが,「出荷する」と いう「動作」と，「台数」という「数え方」で表されてい る.乥して、「1998年度」や「国内」はこの統計量を 限定する「条件」となっている.この例が示す通り，動 作型は, 以下の内部構造を持つと考えられる:

条件, 対象, 動作, 数元方.

\section{$\S 2$ 属性型の統計量名の内部構造}

例文 (7) の「ドバイ原油価格」という統計量名は,「ド バイ」,「原油」「価格」という統計量名の要素から構成 されている「原油」は例文 $(6)$ の「パソコン」と同樣に 統計を取る「対象」である．しかし，「価格」は対象の量 ではなく，対象の持つ「属性」の一つである．また，「ド バイ」は「原油価格」を限定する「条件」となっている． この例が示す通り，属性型は，以下の内部構造を持つと 考えられる:

条件，対象，属性。

\section{$\S 3$ 定義型の統計量名の内部構造}

例文 (8) に関しては, 統計量名は「1月の景気動向指 数」であり,「1月」,「景気動向指数」という要素から構 成されている.ここで,「景気動向指数」は, 何らかの計 算方法によって定義されている量の名前に過ぎず，内部 構造を持たない，一方で,「1月」はこの統計量を限定す る「条件」となっている.この例が示す通り，定義型は， 以下の内部構造を持つと考えられる:

条件, 定義.

$4 \cdot 3$ 統計量名の各要素を注釈付けするためのタグセット 前節の考察に基づき, 統計量名の各要素を分類して抽 出することを目的として，文に注釈付けを行なうために 以下の XML タグセットを独自に用意する .

・動作型に関するタグ

foot 対象が受けた動作「「出荷」「生産」など．

head 統計量の数え方「台数」,「量」など.

prop 統計量の数え方で, 割合で表現したもの.「シェ ア」など．

obj 対象「ビール」など . 
<agent id="DOC1_1, DOC1_2">トヨタ自動車 $</$ agent $>$ のtime id="DOC1_1, DOC1_2"> 19 98 年</time>の<locat id="DOC1_1, DOC1_2"> 国内</locat $><$ foot id="DOC1_1" $>$ 生産</foot $>$ $<$ head id="DOC1_1">台数</head $>$ はわずかに減 少したが , <foot id="DOC1_2">販売く/foot> <head id="DOC1_2" > 台数</head $>$ は増加した .

図 2 提案するタグセットによる注釈付けの例

\section{・属性型に関するタグ}

attr 対象の属性「原油価格」における「価格」など． obj 対象「原油価格」における「原油」など.

・定義型に関するタグ

def 定義された式に従って計算された統計量の名前「景 気動向指数」など .

・「条件」に関するタグ (上記，統計量の各型に共通)

time 統計量の值を集計した期間 .

locat 統計量の值を集計した地域 .

agent 会社名や機関名など.

age 年齢.

add 統計量の值に付加的につけられる条件「合計」「平 均」など .

range 上記以外の, 統計を集計した範囲を表す表現 .

図 2 に上記タグセットにより注釈を付与した例文を示 す.なお，各タグはid 属性を持つ.これは，注釈付けら れた表現がどの統計量名の要素であるかを管理する識別 子のリストを值に持つ. 個々の識別子が，ある個別の統 計量名に対応する . 逆に , 同じ識別子を id 属性の值に 持つ表現を要素として集めた束が一つの統計量名となる． 例えば，図 2 において，識別子 "DOC1_1”, "DOC1_2" に対応する統計量名は, 光れ午れ, \{agent:卜ヨタ自動 車, time: 1998 年, locat:国内, foot:生産, head:台数 \}, \{agent:卜ヨタ自動車, time: 1998 年, locat:国内, foot:販売, head:台数 \}と記すことができる .

\section{5. 文字のチャンキングに基づく統計量名の要 素の自動抽出}

本稿で定義した各要素について, 光の自動抽出の実現 可能性を調べるために，標準的な情報抽出手法によって どれくらいの精度で抽出できるかを調べる . 具体的には， 文字を構成単位としたチャンキング問題として, 統計量 名の要素の抽出を捉える.チャンキングとは, 任意の解 析単位 (トークン)をある視点からまとめ上げていき，ま とめ上げた固まり(チャンク)を, 乥れらが果たす機能ご とに分類することであり，固有表現抽出などで用いられ る.このチャンキング問題は, トークン列に対する系列
ラベリングにより精度良く解くことができることが知ら れている。乥こで, 中野ら [中野 04] が固有表現抽出に 用いた手法と同等のものを用いて, 統計量名の要素の自 動抽出を行なうことを考える.以下の， $5 \cdot 1$ 節， $5 \cdot 2$ 節， $5 \cdot 3$ 節において, 同手法について述べる.

\section{$5 \cdot 1$ チャンクの表現方法}

チャンキングを行う際, チャンクの状態を如何に表現 するかが問題となる. 各種先行研究においては, 各トー クンに対し , チャンクに対する状態を示すチャンクタグ を付与する方法か利用されている . チャンクの状態を表 す符号化の方法としては IOB1 法 , IOE1 法 , IOE2 法 などが提案されているが，SVM を用いた固有表現抽出 においては, IOB2 法を用いた場合が最も精度が良いと 報告されている [山田 02] . 同符号化によるチャンクタグ を「エアコンの 5 月の国内出荷台数が」という文字列に 付与した例を図 3 に示す. 第二列にある各文字について， チャンク内での兴の役割が, 最終列にチャンクタグとし て示されている .チャンクタグは, 対応するトークンの チャンク内での位置を表す記号 (B もしくは I) と, チャ ンクの種類 (time,locat など) をハイフンで結んだもので ある . IOB2 法では , チャンクの先頭に位置するトーク ンにB という位置を表す記号を付与し，弚れに後続する チャンクの部分に対応するトークンに記号 I を付与する . また, 要素以外のトークンには O が付与される . 図 3 に おいては, 文字列「エアコン」「5月」,「国内」,「出荷」, 「台数」が, 光れ光れ, obj,time,locat,foot,head という 種類のチャンクであることを表している．

さて, 固有表現抽出等の情報抽出の先行研究の多くで はトークンとして形態素を用いているが，この手法では 形態素の境界が抽出すべきチャンクの境界と一致しない と正確な抽出ができない . Asahara ら [Asahara 03] は， 文字をトークンの単位として用いることによって, 形態 素解析により認定された形態素の境界と実際の固有表現 の境界との間にある不一致の問題を解消できることを示 している．また，トークンである文字自身を素性として も使用するため形態素产のものをトークンとするよりも 粒度の細かい情報を用いることができる、本稿でも，文 字をトークンの単位とする.

\section{$5 \cdot 2$ 文字を単位とした素性の展開}

文字列中の各文字には年の出現を特徵付ける素性を各 種観点から割り当てることができる，例えば，図 3 にお いて，第 1 , 最終列以外の各列が我々が採用している素性 である。具体的には，素性として，文字自身，文字種，品 詞, 形態素, 文節内素性, 複合名詞主辞素性を採用して いる.文節内素性は，中野ら [中野 04]により提案された 素性であり，文節内に固有表現が存在すれば，最も先頭 に近い固有名詞の品詞細分類を，固有名詞がなければ文 節の先頭の形態素を用いるものである．また , 複合名詞 


\begin{tabular}{|c|c|c|c|c|c|c|c|}
\hline $\begin{array}{l}\text { 位 } \\
\text { 置 }\end{array}$ & $\begin{array}{l}\text { 文 } \\
\text { 字 }\end{array}$ & 文字種 & 形態素 & 品詞 & $\begin{array}{l}\text { 文節内 } \\
\text { 系性 }\end{array}$ & $\begin{array}{l}\text { 複合名詞 } \\
\text { 主辞素性 }\end{array}$ & $\begin{array}{l}\text { チャンク } \\
\text { タグ }\end{array}$ \\
\hline $\mathrm{i}+8$ & I & KATAK & B-エアコン & B-名詞-一般 & エアコン & エアコン & B-obj \\
\hline$i+7$ & P & KATAK & トーエアコン & 1-名詞一般 & エアコン & エアコン & I-obj \\
\hline $\mathrm{i}+6$ & ב & KATAK & トーエアコン & 1-名詞一一般 & エアコン & エンアン & I-obj \\
\hline $\mathrm{i}+5$ & ン & KATAK & E-エアコン & E-名詞一般 & エアコン & エアコン & I-obj \\
\hline $\mathrm{i}+4$ & の & HIRAG & s-の & S-助詞-運体化 & * & * & 0 \\
\hline$i+3$ & 5 & ZDIGIT & B-5月 & B-名詞-副詞可能 & 5月 & 5月 & B-time \\
\hline $\mathrm{i}+2$ & 月 & OTHER & E-5月 & E-名詞-副詞可能 & 5月 & 5月 & I-time \\
\hline$i+1$ & の & HIRAG & s-の & S-助詷-連体化 & * & * & 0 \\
\hline $\mathrm{i}$ & 国 & OTHER & B-国内 & B-名詞-一般 & 国内 & 台数 & B-locat \\
\hline$i-1$ & 内 & OTHER & E-国内 & E-各詞一般 & 国内 & 台数 & I-locat \\
\hline $\mathrm{i}-2$ & 出 & OTHER & B-出荷 & B-名詞-サ変接続 & 国内 & 台数 & B-foot \\
\hline $\mathrm{i}-3$ & 荷 & OTHER & E-出荷 & E-名詞-サ変接続 & 国内 & 台数 & I-foot \\
\hline i-4 & 台 & OTHER & B-台数 & B-名詞-一般 & 国内 & 台数 & B-head \\
\hline i- -5 & 数 & OTHER & E-台数 & E-名詞-一般 & 国内 & 台数 & I-head \\
\hline i- 6 & が & HIRAG & s-trs & S-助詞-格助詞- & * & * & 0 \\
\hline
\end{tabular}

図 3 素性集合に対する分類に基づくチャンクタグの推定

主辞素性とは，我々が新たに導入した素性であり，連続 する名詞が存在する場合，連続する名詞の最後の名詞を 素性とするものである .

なお , 形態素を単位とする場合と異なり，文字には直 接品詞情報を付加することはできない，乥のため中野ら [中野 04] は各文字が属する形態素と光の品詞情報に，光 の文字の形態素中での位置に関する情報を Start-End 法 (以下 SE 法)[内元 00] て符号化した記号を付与したもの を素性として用いている.SE 法ではチャンク(この場合 は形態素) の先頭文字に対し B タグ，末尾に E タグ，内 部に I タグ, 一文字からなるチャンクに対しては $\mathrm{S}$ タグ が付与される．我々も同じ手法により，形態素ならびに 弚の品詞を符号化し素性として利用している。

\section{$5 \cdot 3$ 文字に対応する素性集合の分類に基づくチャンク の抽出方法}

$5 \cdot 1$ 節のとおりチャンクタグが定義される場合, チャ ンキング問題は, 各トークンに対するチャンクタグの付 与という分類問題に帰着される.機械学習に基づく自動 分類手法を利用することを考えると, 統計量名の要素に 関する抽出規則の学習は, 図 3 の $\mathrm{i}$ 番目の文字について, 兴の文脈 (図 3 では文脈長が 5 文字) を表す枠内の素性か ら，対応するチャンクタグ(図 3 では B-locat)を得るよ うな分類器を, 学習事例と機械学習手法を用いて構成す ることに相当する．一方，未知の文における抽出の際に は，各文字毎に枠内の素性集合を導出し，光の素性集合 を分類器に与えることによりチャンクタグを文末から文 頭に向けて順次推定する．なお，解析方向を逆向きにし た右向き解析もある.日本語固有表現抽出においては左 向き解析が有効であることが知られており，本稿の統計 量名の要素の抽出においても左向きて解析を行う.

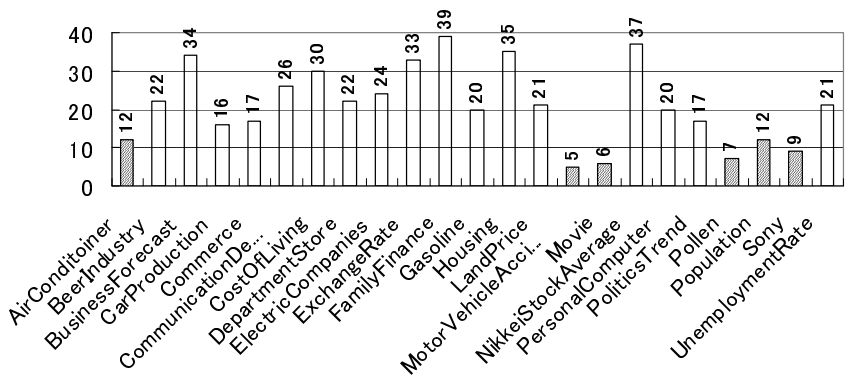

図 4 トピック毎の文書数

表 1 要素表現に関する各種集計結果

\begin{tabular}{|c|c|c|c|c|c|}
\hline & $\begin{array}{l}\text { 延べ } \\
\text { 表㺺 }\end{array}$ & 異な & $\begin{array}{r}\text { 各表現の } \\
\text { 亚均 }\end{array}$ & 延べ表現 & $\begin{array}{r}\text { 各表現の } \\
\text { 亚十分 }\end{array}$ \\
\hline タグ名 & 総数 & 現数 & 延べ数 & 標準偏差 & 文字数 \\
\hline add & 257 & 17 & 15.1 & 32.3 & 1.9 \\
\hline age & 45 & 21 & 2.1 & 2.2 & 6.0 \\
\hline agent & 413 & 83 & 5.0 & 6.0 & 4.4 \\
\hline attr & 495 & 19 & 26.1 & 27.3 & 1.7 \\
\hline def & 183 & 23 & 8.0 & 11.4 & 4.9 \\
\hline foot & 633 & 36 & 17.6 & 29.2 & 2.0 \\
\hline head & 402 & 13 & 30.9 & 38.4 & 1.6 \\
\hline locat & 540 & 117 & 4.6 & 14.4 & 3.1 \\
\hline obj & 765 & 151 & 5.1 & 10.3 & 3.1 \\
\hline prop & 239 & 8 & 29.9 & 41.4 & 1.7 \\
\hline range & 2094 & 529 & 4.0 & 8.6 & 4.3 \\
\hline time & 2017 & 484 & 4.2 & 14.3 & 3.9 \\
\hline
\end{tabular}

\section{6. 統計量名の要素に関する自動抽出実験}

前節で述べた標準的チャンキング手法を用いることに よって, 我々が定義した統計量名の各要素がどれくらいの 精度で抽出できるかを調べるために，抽出実験を行った．

\section{$6 \cdot 1$ 実 験 の 設 定}

実験には MuST コーパス (2006 年版) を用いた [加藤 04] . MuST コーパスは毎日新聞 1998 年度版，1999 年度 版の新聞記事から，統計量や出来事に関する 27 のトピッ クに従って文書を集めたものであり，統計量等に関する 注勫づけが人手で行なわれている．MUST コーパスのう ち，統計量の動向情報に関する 23 トピック，485 記事に 対し，MuST で定義された注釈を取り除き，代りに，4・3 節で定義したタグセットにより注釈を人手で付与したも のを用いた .このコーパスの基本情報として , 各トピッ ク毎の文書数を図 4 に, 統計量名の要素として出現した 表現について各種観点から集計した結果を表 1 に示す．

なお，抽出実験には，SVMに基づく汎用チャンカーで ある YamCha[Kudo 01] を使用し, チャンクの解析方向 は左向き解析で行い, チャンクの状態を表す符号化方法 にはIOB2 を利用し, 文脈長は対象文字の前後 2 文字ず つ計 5 文字とした . 


\section{$6 \cdot 2$ 実験 1: 提案したタグセットに基づく 統計量名要 素表現の抽出実験}

$6 \cdot 1$ 節で隼備した注釈付きコーパスに対し交差検定を 行い, 適合率 , 再現率により抽出精度の評価を行なった . 各トピックには特定分野のテキスト集合が個別に収録さ れているので, 次の 2 種類の交差検定を行なった . 分野混合交差検定 各卜ピックの文が混合された状態で

均一に現れるように 10 個の部分コーパスに分割し， 10 分割交差検定を行なったもの.

分野別交差検定 22 個のトピックに属する文書集合を併

せて学習用コーパスとし，残りの 1 つのトピックに

属する文書集合を評価用コーパスとして，23 分割交 差検定を行なったもの .

前者の分野混合交差検定の結果を調べれば，抽出対象と なっている文書領域について学習用の注釈付コーパスが 入手可能な場合における抽出精度が分かり，後者の分野別 交差検定の結果を調べれば, 対象文書領域の学習用コー パスが入手できない時に，他分野の学習用コーパスで代 用する場合における抽出精度が分かる.

さらに，5・2 節で我々か導入した複合名詞主辞素性が 本タスクにおいて有効に機能したか否かを確認するため に，分野混合交差検定により，同素性を有効にした場合 と無効にした場合とで抽出精度に違いがあるか否かを調 査した。

\section{6・3 実験 2: MuST コーパスに基づく 統計量名表現の 抽出実験}

更に, 統計量の名前を要素ごとに抽出する手法が, 統 計量の名前を文書に現れる关のままの形で抽出する場合 と比べて, 抽出精度の観点において, どのような得失が あるかを調べることを目的として比較実験を行なった MuST コーパスにおいては，次の例文ように，統計量名 が name 要素により注釈づけられている .

(9) $\ulcorner\langle$ name $\rangle$ 乗用車の生産台数 $\langle/$ name $\rangle$ は 473 万台 5374 台で, 前年同期比 $12 \cdot 1 \%$ の大幅減少であった 」

(10)「日本市場に最も影響のある〈name $\rangle$ 中東産ドバイ 原油価格〈/name〉は 2 月から高騰した 」

name 要素は, 我々が定義した統計量名の主要要素に相 当する表現に対し，文書に現れる光のままの形で一塊と して注釈づけを行なったものと考えることができるため， MuST コーパスにおける name 要素の抽出精度を調へ， 我々の定義したタグセットの場合と比較検討をすること により，先の目的を達することができる．ただし，MuST コーパスの name 要素の抽出においては, $3 \cdot 2$ 節で述べた 「取り出された要素を組み合わせて 1 つの統計量名を作る タスク」も一部含まれていることに注意されたい . name 要素で定義される連続した文字列に現われる統計量名の 要素について, 要素の種類は判別しないものの, 弚の組 が抽出されるからである.一方で, name 要素に現われ る統計量名 (の一部)を, 記事中の別の部分に登場する要

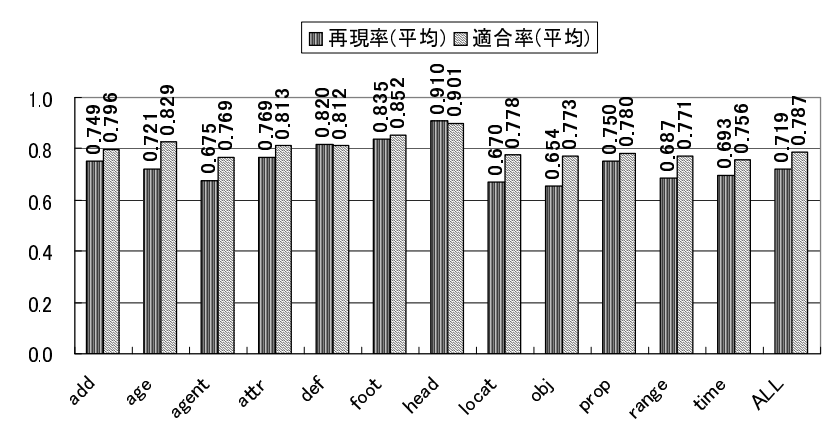

図 5 各要素の自動抽出に関する適合率と再現率 (分野混合交差 検定)

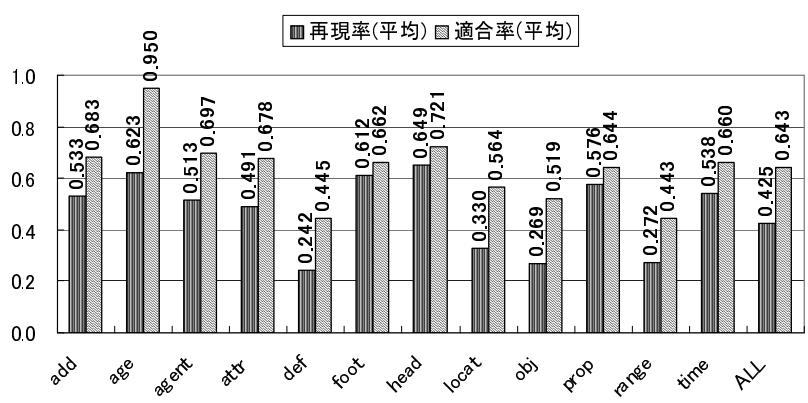

図 6 各要素の自動抽出に関する適合率と再現率 (分野別交差検定)

素と組み合わせる必要がある場合があるので,「取り出さ れた要素を組み合わせて 1 つの統計量名を作るタスク」 は別途必要となる .

さて，MuST コーパスにおける name 要素の抽出実験 は, $6 \cdot 2$ 節における分野混合交差検定の場合と同等の手 法を用いた .ただし, MuST コーパスでは unit 要素で囲 まれている文にしか name 要素が存在しないため, unit 要素で囲まれた文以外は実験の対象としなかった .

\section{$6 \cdot 4$ 実 験 結 果}

実験 1

各要素の自動抽出の精度評価を, 分野混合交差検定な

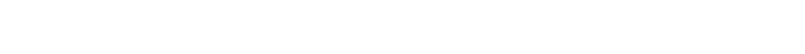
5 ならびに図 6 に示す．また，分野別交差検定において， 再現率, 適合率について平均值を求める前の, 分野毎の 要素抽出精度を, 要素に瓦るマイクロ平均により求めた ものを図 7 に示す.さらに，複合名詞主辞素性の有無を 変えて, 分野混合交差検定により要素の抽出精度を要素 に互るマイクロ平均で求めたものを表 2 に示す.

表 2 複合名詞主辞素性の有無による抽出精度の違い

\begin{tabular}{|c|c|c|}
\hline & \multicolumn{2}{|c|}{$\begin{array}{l}\text { 複合名詞 } \\
\text { 主辞素性 }\end{array}$} \\
\hline & 有 & $\begin{array}{l}\text { 無 } \\
\end{array}$ \\
\hline 再現率 & 0.719 & 0.712 \\
\hline 適合率 & 0.787 & 0.788 \\
\hline
\end{tabular}




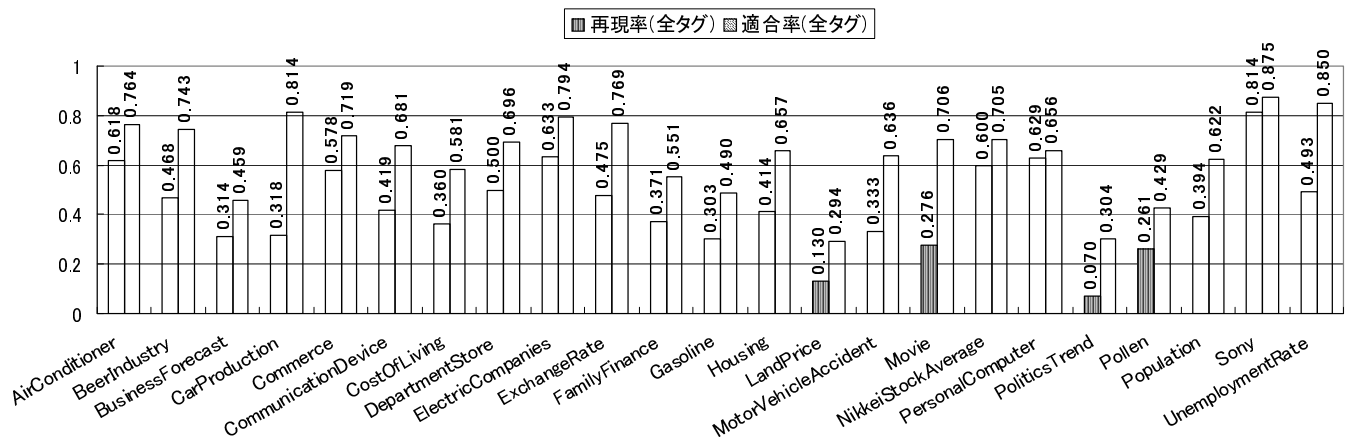

図 7 分野別交差検定における分野別の要素自動抽出に関する適合率と再現率 (マイクロ平均)

実 験 2

MuST コーパスにおける name 要素の抽出精度を表 3 に示す . 同表には , 表 1 と同樣に統計量名表現について 各種観点から集計した結果をまとめるとともに，比較の ために, 我々が定義した統計量名の要素の抽出結果等に ついて再掲する．

\section{7. 考察}

\section{$7 \cdot 1$ 分野混合交差検定結果に基づく考察}

分野混合交差検定の結果に基づき，抽出対象となって いる文書領域について学習用の注釈付コーパスが入手可 能な場合における抽出精度について議論する．

\section{$\S 1$ 動作型に関するタグの抽出}

動作型に関するタグには, 主要素として foot, head, prop, obj が定義されている.「動作」に対応する foot は 適合率，再現率ともに 0.8 を越えており，「数え方」に対 応する head に関しては適合率, 再現率の両者が 0.9 以上 であった . また , head と同等で数え方に対応するが, 值 を「割合」により表現する prop については, head の抽 出精度よりも若干低いものの, 再現率 0.75 , 適合率 0.78 となっている .これらのことより, 動作型の主要素をあ る程度の精度で自動抽出できると考えられる．表 1 によ れば，これらのタグによって注釈づけられる表現の平均 延べ数が 18 から 30 と多く，延べ表現数の標準偏差も大 きいことから，一部の表層表現に出現か偏っていること が伺える. また，平均文字数も 2 以下と小さい . 兴のた め, これらの要素の出現状況が学習されやすかったので はないかと考えられる .

なお，対象に対応する obj タグに関しては，属性型の 対象と共有しているため次項で考察する .

\section{$\S 2$ 属性型に関するタグの抽出}

属性型に関するタグには，attr,objがある . 属性型の 統計量の主要素であり属性に対応する $\mathrm{attr}$ は , 適合率は ほぼ 0.8 ではあるが, 再現率は 0.77 と若干低い結果と なった .これは動作型の数え方 (head) と違い , 属性には 樣々な表現があり学習が不十分であったためだと考えら れる .
また，対象に対応する obj に関しても，やはり，再現 率が 0.67 と低い．表 1 に示すように , objは異なり表現 数が多く，また，平均文字数も 3.1 と若干大きい，关の ために, 我々が準備したコーパスでは, 学習が不十分で あったことが考えられる．

\section{$\S 3$ 定義型夕グの抽出}

定義型の統計量名の主要素であり定義に対応する def に関しては適合率，再現率ともにほぼ 0.8 を越えている。 $\operatorname{def}$ は平均文字数が 4.9 と他の要素よりも大きいが, 異な り表現数が foot や head と同程度であり，ある程度定型 の表現により出現していることが伺える．

\section{$\S 4$ 条件に関するタグの抽出}

条件に関するタグについて, 適合率は 0.77 程度以上 と，ある程度の值となったが，再現率は全体的に低く，特 に地域を示す locat が 0.67 と低い.これは attrや obj と同樣に, 文書に現れる地域の表現が多いのに対し，学 習データの量が十分でなかったためであると考えられる． 今後は, 別のコーパス等で学習を行なった固有表現抽出 器の出力と組み合わせることなどにより, 精度を向上さ せる手法を検討すべきである .

一方で，期間を示す time に関しては統計量に関連し ない時間表現も抽出してしまっている．例えば，

(11)「国内自動車メーカー大手 5 社は 1997 年の生産, 販 売, 輸出実績を発表した . 4 月の消費税率アップによる 消費不振で国内販売が落ち込んだ.」

という文章において「4月」という表現は統計量名の要素 ではないが，このような時間表現も抽出をすることがあ る.しかしながら, 誤って抽出した期間に関しては，取り 出された要素を組み合わせて 1 つの統計量名を作るタス ク」において，対応することが可能であると考えられる．

\section{$\S 5$ 複合名詞主辞素性の有無による抽出精度の違い}

表 2 によれば，複合名詞主辞素性を追加することによ り, 統計量名の要素の抽出において, 適合率をほとんど 低下させずに, 再現率を若干ながら向上させる効果があ ることが分かった . 
表 $3 \mathrm{MuST}$ コーパスの name 要素との抽出精度の比較

\begin{tabular}{|c|c|c|c|c|c|c|c|}
\hline タグ名 & 再現率 & 適合率 & 延べ表現総数 & 異なり表現数 & $\begin{array}{r}\text { 各表現の } \\
\text { 平均延べ数 }\end{array}$ & $\begin{array}{r}\text { 延べ表現数の } \\
\text { 標準偏差 }\end{array}$ & $\begin{array}{r}\text { 各表現の } \\
\text { 平均文字数 }\end{array}$ \\
\hline $\begin{array}{l}\text { MuST } \\
\text { name }\end{array}$ & 0.747 & 0.737 & 1570 & 489 & 3.2 & 5.7 & 6.2 \\
\hline foot & 0.835 & 0.852 & 633 & 36 & 17.6 & 29.2 & 2.0 \\
\hline head & 0.910 & 0.901 & 402 & 13 & 30.9 & 38.4 & 1.6 \\
\hline attr & 0.769 & 0.813 & 495 & 19 & 26.1 & 27.3 & 1.7 \\
\hline def & 0.820 & 0.812 & 183 & 23 & 8.0 & 11.4 & 4.9 \\
\hline obj & 0.654 & 0.773 & 765 & 151 & 5.1 & 10.3 & 3.1 \\
\hline
\end{tabular}

\section{$7 \cdot 2$ 分野別交差検定結果に基づく考察}

図 6 を图 5 と比較すると，ある分野のコーパスで学習 した結果を，別の新しい分野のコーパスに適用したとき に，精度低下が認められる.図 7 によれば，これは分野 の近さによるところが大きいことがわかる . 例えば , 分 野「エアコン (AirConditioner)」,「総合電器 3 社 (ElectricCompanies)」「ソニー (Sony)」については , 大きな 精度低下か認められないが, これは, 光の中の 1 分野が 評価されるときに, 残り 2 つの類似した分野が学習デー タとして機能していたためだと考えられる .

\section{$7 \cdot 3 \mathrm{MuST}$ コーパスで定義されるタグセットとの比較} 検討

表 3 を見ると, 本稿で提案した統計量名の各主要要素 について, obj を除くと, 弚の自動抽出精度は name 要 素より良い抽出精度となっている。

name 要素は例文 (9) では「乗用車の生産台数」, 例 文 (10)では「中東産ドバイ原油価格」となっているが， このように統計量の名前を一塊として扱うと，樣々な長 い表現で文書中に表出する . 表 3 に示すとおり，各表現 の平均文字数は 6.2 と長く, 平均延へ数は 3.2 と小さい 产のため, 学習が十分になされず精度が低くなったと考 えられる。

一方で, 本稿て定義した統計量名の主要要素 foot, head, attr については, 各表現の平均文字数が 2 文字以下と短 く, 平均延へ数も 18 から 30 と大きい. これらの傾向よ り，一塊の統計量名としては異なる表現ではあるが, 適 切な要素に分解すれば, 产の要素が多数の統計量名にお いて共有されていることがわかる．弚のために，学習が 進み精度が高くなったと考えられる。

なお, objに関しては, 他の主要要素や MuST の name 要素に比べて自動抽出の再現率が低い．これは，統計量 名の構成要素において, obj の抽出か溡に難しいためであ るが, 逆にいうと, 統計量名において, この obj を分離 して抽出することにより，抽出精度の悪さを obj の範囲 に限定することができているとみなすこともできる .こ のことは, 今後の課題となる抽出精度向上において, 注 力すべき要素を絞り込むことができることを示唆するも のである .

\section{8.おわりに}

本稿では, 動向情報の要約と可視化を背景に, 新聞記 事からの統計量表現の抽出を目的とし, 統計の調査方法 と統計量名を定義することで，統計量名の抽出を検討し た、統計量名は樣々な要素から構成されているため, 動 作型, 属性型, 定義型という 3 種類の統計量名の内部構 造を考察し，光れ光れの要素の抽出実験を行った．

兴の結果，統計量名の構造を分類することで, 沉用チャ ンカーに基づく標準的な抽出方法を用いても，ある程度 の精度で統計量名の要素を抽出できることがわかった . ま た，MuST コーパスで用いられている統計量の名前を表 す name 要素と抽出精度を比較をすることで, 統計量名 を要素ごとに抽出するほうが精度が高くなることが示さ れた . 統計量名を要素ごとに抽出することで, 可視化な どを行う際に統計の調査方法が同一のものであるかを判 定しやすくなると考えられる . 一方で, 分野混合交差検 定の結果と，分野別交差検定の結果の比較により，類似 した分野の注釈付き学習用コーパスが利用できる場合に は，抽出精度が高いのに対して，弚のようなコーパスが なく, 別分野の学習用コーパスを流用しなければならな い場合には，抽出精度が低くなることが確認された 。

自動抽出において統計量とは関係のない期間などを抽 出してしまっているが, これらは統計量名の抽出タスク の 2 つ目である「取り出された要素を組み合わせて $1 つ$ の統計量名を作るタスク」において除去することができ ると考えられる .

今後の課題としては，統計量名の抽出で残された $2 つ$ のタスク ,すなわち ,

・取り出された要素を組み合わせて 1 つ統計量名を 作るタスク

・統計の調査方法が同じものを判定するタスク を実現する手法の検討がある．また，動向情報の要約や 可視化を自動化するためには，統計量の值の抽出や，光 の值がどの統計の調査方法と組になるかを判定すること も必要である。

\section{謝辞}

本研究では, 国立情報学研究所主催の評価型ワークシ ヨップNTCIR におけるパイロットワークショップ MuST の研究用データセット (動向情報コーパス) を利用させて 
いただいております．MuST を運営されている皆樣に感 謝いたします。

また , 本論文の執筆にあたっては，MuST の参加者の 皆樣からいただきました樣々なコメント，ならびに，本 論文を査読して下さった匿名の査読者の方々のコメント が大変参考になりました . 感謝いたします．

なお, 本研究の一部は, 科学研究費補助金・基盤研究 (C)(課題番号 19500118)の支援を受けている.

\section{$\diamond$ 参 考 文 献 $\diamond$}

[Asahara 03] Asahara, M. and Matsumoto, Y.: Japanese Named Entity Extraction with Redundant Morphological Analysis, in Proceedings of HLT-NAACL 2003 (2003)

[Kudo 01] Kudo, T. and Matsumoto, Y.: Chunking with support vector machines, in Proceedings of NAACL 2001, pp. 1-8 (2001)

[内元 00] 内元 清貴, 馬 青, 村田 真樹, 小作 浩美, 内山 将夫, 井 佐原 均 : 最大エントロピー法と書き換え規則に基づく日本語 固有表現抽出, 情報処理学会論文誌, Vol. 9, No. 1, pp. 63-90 (2000)

[加藤 04] 加藤 恒昭, 松下 光範, 平尾 努 : 動向情報の要約と可 視化に関するワークショップの提案, 自然言語処理研究会報告 2004-NL-164, 情報処理学会 $(2004)$

[斉藤 98] 斉藤 公一, 迫田 昭人, 中江 富人, 岩井 禎広, 田村 直 良, 中川 裕志 : 数值情報をキーとした新聞記事からの情報抽出, 自然言語処理研究会報告 98-NL-125, 情報処理学会 (1998)

[斎藤 07] 斎藤 悠, 河合 英紀, 土田 正明, 水口 弘紀, 久寿居 大: 新聞記事コーパスからの統計量表現自動抽出と共起関係ネット ワーク構築, MuST「動向情報の要約と可視化に関するワーク ショップ」第二回成果進捗報告会論文集 $(2007)$

[中野 04] 中野桂吾, 平井 有三:日本語固有表現抽出における文節 情報の利用, 情報処理学会論文誌, Vol. 45, No. 3, pp. 934-941 (2004)

[藤畑 01] 藤畑 勝之, 志賀 正裕, 森 辰則 : 係り受けの制約と優先規 則に基づく数量表現抽出, 自然言語処理研究会報告 2001-NL-145, 情報処理学会 $(2001)$

[村田 06] 村田 真樹,一井 康二, 馬 青, 白土 保 : MuST データを 利用した自動動向調査システムの開発, 言語理解とコミュニケー ション研究会報告 NLC2005-119, 電子情報通信学会 (2006)

[山田 02] 山田 寛康, 工藤 拓, 松本 裕治 : Support Vector Machine を用いた日本語固有表現抽出，情報処理学会論文誌，Vol. 43, No. 1, pp. 44-53 (2002)

〔担当委員 : 桝井 文人〕

2007 年 11 月 29 日 受理

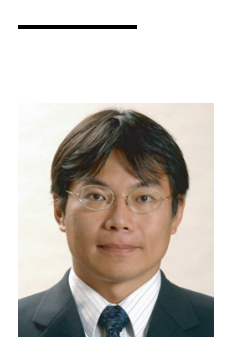

\section{紹 介}

\section{森辰則(正会員)}

1991 年横浜国立大学大学院工学研究科博士課程後期修了 工学博士 . 同年, 同大学工学部助手着任 .同講師, 同助教 授を経て, 現在, 同大学大学院環境情報研究院教授 .この 間，1998 年 2 月より 11 月まで Stanford 大学 CSLI 客員研究員 . 自然言語処理, 情報検索, 情報抽出などの研 究に従事、言語処理学会, 情報処理学会, 日本ソフトウェ 乃科学会, ACM 各会員.

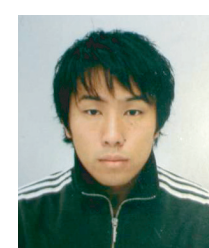

\section{藤岡 篤史}

2007 年横浜国立大学大学院環境情報学府情報メディア環 境学専攻博士課程前期修了. 同年日立製作所入社 . 現在 情報・通信グルーブ勤務 · 在学中は自然言語処理に関する 研究に従事。

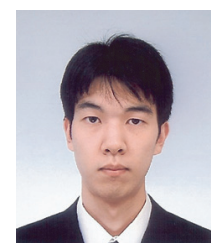

\section{村田 一郎}

2007 年横浜国立大学大学院環境情報学府情報メディア環 境学専攻博士課程前期修了. 同年総務省入省. 現在, 独立 行政法人統計センター勤務・横浜国立大学大学院在学中は 自然言語処理に関する研究に従事。 